\title{
Impulse Radar Scanning of Intact Salt at the Avery Island Mine
}

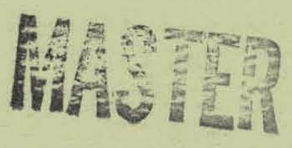

C. Wayne Cook

Prepared by Sandia Laboratories, Albuquerque, New Mexico 87185 and Livermore, California 94550 for the United States Department of Energy under Contract DE-AC04-76DP00789

Printed May 1980 


\section{DISCLAIMER}

This report was prepared as an account of work sponsored by an agency of the United States Government. Neither the United States Government nor any agency Thereof, nor any of their employees, makes any warranty, express or implied, or assumes any legal liability or responsibility for the accuracy, completeness, or usefulness of any information, apparatus, product, or process disclosed, or represents that its use would not infringe privately owned rights. Reference herein to any specific commercial product, process, or service by trade name, trademark, manufacturer, or otherwise does not necessarily constitute or imply its endorsement, recommendation, or favoring by the United States Government or any agency thereof. The views and opinions of authors expressed herein do not necessarily state or reflect those of the United States Government or any agency thereof. 


\section{DISCLAIMER}

Portions of this document may be illegible in electronic image products. Images are produced from the best available original document. 


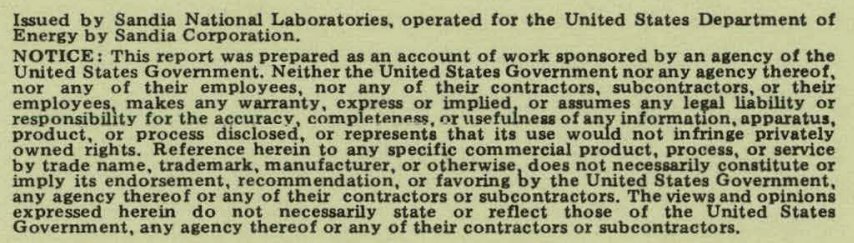

Issued by Sandia National Laboratories, operated for the United States Department of
Energy by Sandia Corporation. NOTICE: This report was prepared as an account of work sponsored by an agency of the nor any of their employees, nor any of their contractors, subcontractors, or the responsibility for the accuracy, express or implied, or assumes any legal hability owned rights. Reference herein to any specific commercial product, process, or servic ny agency thereof or any of their contractors or subcontractors. The views and opinion

Government, any agency thereof or any of their contractors or subcontractors.

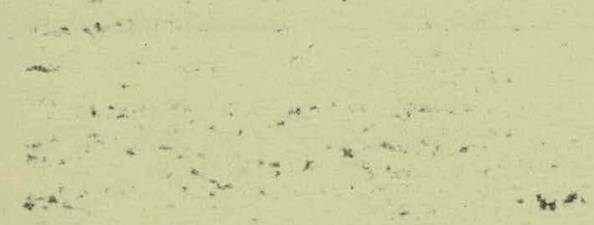

Printed in the United States of America

Available from

National Technical Information Service

U. S. Department of Commerce

5285 Port Royal Road

Springfield, VA 22161

Price: Printed Copy $\$ 4.50$; Microfiche $\$ 3.00$

6.5 
SAND80-0632

Unlimited Distribution

Printed

\title{
IMPULSE RADAR SCANNING OF INTACT SALT AT THE AVERY ISLAND MINE
}

\author{
C. W. Cook \\ Sandia National Laboratories \\ Albuquerque, New Mexico
}

\begin{abstract}
A acrice of experiments was run in the Avery Island Mine to evaluate the capability of an impulse radar to locate anomalies and simulated waste targets in intact dome salt. Voids in salt were difficult to detect. On the positive side, metal targets and simulated waste (glass) were easily located in intact salt. Radar scannning at ranges of greater than 25 meters and short-range resolution of target positions to within a few centimeters were achieved.
\end{abstract}

This book was prepared as an account of work sponsored by an agency of the United States Government. Neither the United States Government nor any agency thereof, nor any of their employees, makes any warranily. express or imolied. of assymes any legal liability or responsibility for the eccuracy. completeness, of usefulness of any information, epparatus, product, or process disclosed, or represents inat its use would not iniringe privately owned rights. Reterence herein to any specific not necescrily consiluto or imoly ins cnoreme

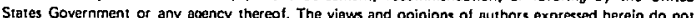
necessarily state or refilect those of the United States Government or eny aenoy thereat. 


\section{ACKNOWLEDGMENT}

The experiments reported were conducted with assistance from E. S. Ames (1116), C. B. Kinabrew (1116), and R. C. Shear. (1116). H. A. Sumlin (4541) and R. G. Stickney (RE/SPEC) prepared the test holes. Also the assistance of A. R. Sattler (4732) in preparing the test plans and coordinating the activities is gratefully acknowledged. 


\section{LIST OF TABLES}

1. Experiment Matrix, Simulated Waste, and Canister Location

2. Data from Radar Scans

\section{LIST OF FIGURES}

1. Block Diagram of Radar System

2. Radar System in Avery Island Mine

3. A Portion of the 500-foot Level of the Avery Island Mine

4. Scan of Pillar A

5. A Vertical Scan of Pillar A

6. Scan of Pillar B

7. Scan of Pillar C

8. Radar Scan, Hole 1

9. Radar Scan, Hole 2

10. Radar Scan, Hole 3

11. Radar Scan, Hole 4

12. Radar Scan, Hole 5

13. Radar Scan, Hole 6

\section{APPENDIX}

I. PROCEDURE FOR ADDING WATER TO AVERY ISLAND BACKFILL SAND/CLAY MIX 


\section{INTRODUCTION}

If intact salt is to be used for the storage of nuclear wastes, it may be necessary to identify inclusions, structural discontinuities, and other anomalies within intact salt prior to excavation. This identification would provide an additional measure of operational safety during construction. Impulse radar is one tool that could be used for scanning intact salt.

This report discusses the results of the Avery Island mine radar experiments ${ }^{1}$ conducted with the cooperation of the office of Nuclear Waste Isolation (ONWI), RE/SPEC Inc. (under contract to ONWI), and Avery Island mine management. The experiments included a measurement of propagation velocity, scanning of three pillars, and the location of simulated nuclear waste and waste canisters.

\section{IMPULSE RADAR SYSTEM}

A Geophysical Survey Systems, Inc. (GSSI) SIR-7 impulse radar was used for the Avery Island experiments. Figure 1 is a block diagram of the radar system.

Burehole transduoers with a center frequency of $100 \mathrm{MHz}$ were used for the propagation velocity measurements. Four hundred $\mathrm{MHz}$ and $1 \mathrm{GHz}$. transducers, each having a transmitting and receiving antenna in a single package, performed the scans. One hundred $\mathrm{MHz}, 400 \mathrm{MHz}$, and $1 \mathrm{GHz}$ are the center frequencies of the Fourier spectrum of the transmitted impulses. The Fourier spectrum is very flat around the center frequency, and rolls off at approximately $20 \mathrm{db} /$ octave at the upper (500 $\mathrm{MHz}$ for $400 \mathrm{MHz}$ transducer) and lower (150 MFz for $400 \mathrm{MHz}$ transducer) frequencies in the spectrum. 
Impulses from the transducer are transmitted into the medium every 20 microseconds. The Sandia system is adjusted so that the receiver can look for echoes for up to 1.2 microseconds. This translates into a potential range of greater than 120 meters. After amplification, the received signals are sampled for recording both on a graphic recorder for field use and on magnetic tape for subsequent signal processing. Figure 2 shows the radar system setup in the mine.

The time base for the radar system is calibrated using the transit time of an impulse through a precise length of coaxial cable. This scheme gives a time base accuracy of a few tenths of a nanosecond.

\section{PROPAGATION VELOCITY}

Propagation velocity was measured so that the range of observed targets could be determined. Avery Island dome salt propagation velocity was measured by transmitting impulses between two boreholes in the oNwT test area. The holes had been drilled for the simulated waste and waste canister experiments described later in this paper. The two boreholes used were 8 inches in diameter, 2.26 meters deep, and 54.97 meters apart. Transmission time between the holes was 422.7 nanoseconds. This gives a propagation velocity of $0.130 \mathrm{~m} / \mathrm{nannserend.} \mathrm{The} \mathrm{propngation} \mathrm{veluclty} \mathrm{of} \mathrm{radar} \mathrm{impulses}$ in air is $0.300 \mathrm{~m} /$ nanosecond.

\section{PILLAR SCANNING}

Four pillar scans were run on the 500-foot level of the Avery Island mine using the $400 \mathrm{MHz}$ transducer. Figure 3 is a map of the mine showing where the pillar scans were run. The first scan was run along the east side of Pillar A. Figure 4 shows the results of this scan. A weak signal can be 
seen at the west salt-air interface of pillar A. The vertical grid marks on this scan and on all other scans (except those shown in Figure 5) were manually placed on the records every $3.05 \mathrm{~m}$ (10 feet) of travel. Using the measured propagation velocity in salt, the radar indicates that the pillar thickness lies between 22.8 and 23.4 meters. These values are consistent with the physical dimensions of the pillar. Figure $4 \mathrm{~B}$ is a replay of the data shown in Figure $4 \mathrm{~A}$ using the range gain function of the radar. In this case, the interface signal is made much clearer.

A second scan was run on Pillar $A$ in an attempt to see the 8 -inch hole located approximately 16 meters from the south side of Pillar A and running from the east side. This scan was run by moving the transducer vertically 4.5 meters from the east side. The results of this scan are shown in Figure 5A. Grid marks were placed on the scan at the start, top, and end of the scan. A clear reflections is seen at 10.7 meters. An inspection of the pillar showed that this target was an extensometer that RE/SPEC had installed in the pillar. The weak signal seen at 16.5 meters is believed to be the open 8 -inch borehole. Figure $5 B$ is a repeat of scan $5 A$; however, in this scan the borehole caliper had been inserted in the hole. A slight 1 ncrease in the signal from 16.5 meters can bè seen.

The second pillar scanned was the triangular pillar, B, shown in Figure 3. The results of this scan (along the long side) are shown in Figure 6A. Several sharp targets were picked up, but they do not correspond to the opposite salt-air interface. It is believed that these signals came from discarded pipes and other metal debris left in the mine. The salt-air interface of the pillar shows faintly at both ends of the scan. Replaying the scan using range gain did not bring out the salt-air interface, Figure $6 \mathrm{~B}$. 
The final pillar scan, $C$ in Figure 3, was run from the point along the northeast side. Figure 7A shows the results of this scan. In this scan, the salt-air interface shows a weak signal. A stronger signal is picked up from the pillar across the drift (D). Replaying the data with range gain improved the detection of the opposite salt-air interface, Figure 7B.

\section{LOCATION OF SIMULATED NUCLEAR WASTE AND WASTE CANISTERS}

To conduct experiments on location of simulated nuclear waste and waste canisters, RE/SPEC drilled four holes on the west side and two holes on the east side of their test area (Figure 1). A backfill getter material (sand with 108 clay) was supplied by Sandia Laboratories' Division 5812 to install as simulated packages. The experiment matrix as constructed is summarized in Table 1.

The radar scans for the six holes are shown in Figure 8 , Hole 1; Figure 9, Hole 2; Figure 10, Hole 3; Figure 11, Hole 4: Figure 12, Hole 5; Figure 13, Hole 6 .

Table 2 summarizes the data read from the radar scans. As the data show, all the simulated targets were detected. The accuracy of locating the top of the targets varied between 2 and $3 \mathrm{~cm}$. The bottoms of the targets, which coincided with the bottoms of the holes, were located with accuracies varying between 1.3 and $6.1 \mathrm{~cm}$. In three out of the four cases where a dry getter-crushed salt interface existed, it was detected. The wet gettercrushed salt interface was easily detected.

The $400 \mathrm{MHz}$ transducer took all the data presented in this section. The same scans were run with the $1 \mathrm{GHz}$ transducer. Only Hole 2 showed readable results. These data were inferior to the $400 \mathrm{GHz}$ data and were not included. 
DISCUSSION AND CONCLUSIONS

The most interesting observation made during the Avery Island scans was the difficulty in detecting a salt-air interface. Conversely, an air-salt interface was easily detected. It was easy to measure the heights of ceilings in the various drifts. Theoretically, these two situations should provide the same echo. However, the situation in which we were looking for a void through a pillar was a little different, because it involved air-saltair interfaces. It is theoretically possible in this situation for the salt to behave as a half-wave dielectric window, if its thickness is an integral number of half-wavelengths. At $400 \mathrm{MHz}$, a half-wavelength in salt is $.163 \mathrm{~m}$. However, it seems a little unlikely that a significant amount of the energy in the transmitted pulse would be negated by this mechanism. Improved range gain amplifiers are now available for the GSSI radar systems. It is possible that this new circuitry might enhance the ability to detect a void in salt. As the system now stands the ability of the impulse radar to detect a gas-filled void in salt is marginal.

On the positive side, the impulse radar easily detects metal and glass targets in salt. Ranye accuracy is aloo quite good. Targets can be located to within a few centimeters. No brine targets were available, but the large reflections seen from the wet floor near the start of the scans on Hole 5 (Figure 12) imply that brine should provide reflections comparable to metal targets. 
TABLE I. EXPERIMENT MATRIX, SIMULATED WASTE AND CANISTER LOCATION

\begin{tabular}{|c|c|c|c|c|c|c|}
\hline Hole & Dia. & Depth & & Simulated Waste & Sand/Clay Mix & Crushed Salt \\
\hline 1 & 8 in & 2.262 & m & $\begin{array}{l}\text { crushed glass } \\
5 " D \times 36 " L\end{array}$ & first $1.323 \mathrm{~m}$ & $\begin{array}{l}\text { sand/clay to } \\
\text { surface }\end{array}$ \\
\hline 2 & 8 in & 2.240 & $\mathbf{m}$ & $\begin{array}{l}\text { stainless steel } \\
\text { tube with titan- } \\
\text { ium end cap } \\
\text { j" D } \times 24^{n} \text { L }\end{array}$ & first $.972 \mathrm{~m}$ & $\begin{array}{l}\text { sand/clay to } \\
\text { surface }\end{array}$ \\
\hline 3 & 3 in & 2.271 & $\mathrm{~m}$ & $\begin{array}{l}\text { stainless steel } \\
\text { tube with titan- } \\
\text { ium end cap } \\
2^{\prime \prime} \mathrm{D} \times 24^{\prime \prime} \mathrm{L}\end{array}$ & first $1.332 \mathrm{~m}$ & $\begin{array}{l}\text { sand/clay to } \\
\text { surface }\end{array}$ \\
\hline 4 & 3 in & 2.243 & $\mathrm{~m}$ & $-\div$ & $\begin{array}{l}\text { first } 1.305 \mathrm{~m} \\
\text { (as provided } \\
\text { dry) }\end{array}$ & $\begin{array}{l}\text { sand/clay to } \\
\text { surface }\end{array}$ \\
\hline 5 & 3 in & 2,256 & m & $=0$ & $\begin{array}{l}\text { firct } 1.289 \mathrm{~m} \\
\text { (double water } \\
\text { content) }\end{array}$ & $\begin{array}{l}\text { gand,elay to } \\
\text { surface }\end{array}$ \\
\hline 6 & 3 in & 2.268 & m & $-\infty$ & $-\infty$ & $\begin{array}{l}\text { entire hole } \\
\text { fllled with } \\
\text { salt }\end{array}$ \\
\hline
\end{tabular}

*See Appendix I for mixing procedure. 
Hole 1

Distance to backfill

Distance to glass target

Hole depth

Hole 2

Distance to backfill

Distance to steel target Hole depth

Hole 3

Distance to backfill

Distance to steel target

Hole depth

Hole 4

Distance to backfill

Hole depth

Hole 5

Distance to backfill

Hole depth

$.966 \mathrm{~m}$

$2.256 \mathrm{~m}$

$.966 \mathrm{~m}$

$2.271 \mathrm{~m}$

Hole 6

Hole depth

$2.268 \mathrm{~m}$

$2.295 \mathrm{~m}$

* Distance to filling nipple

**Very faint signal 
REFERENCES

1. C. W. Cook and A. R. Sattler, Test Plan - Scanning of Intact Salt in the Avery Island Mine with Radar, November 19, 1979, Sandia National Laboratories. 
PROCEDURE FOR ADDING WATER TO AVERY ISLAND BACKFILL SAND/CLAY MIX

1. Adjust amount of material in one plastic bag to 40 pounds.

2. Add 1 quart of water according to the following procedure:
a. Sprinkle $1 / 10$ quart on surface of 40 pounds of backfill.
b. Roll material by raising opposite sides of bag 2 feet for 10 cycles.
c. Repeat $a$ and $b$ for a total of 10 times. 


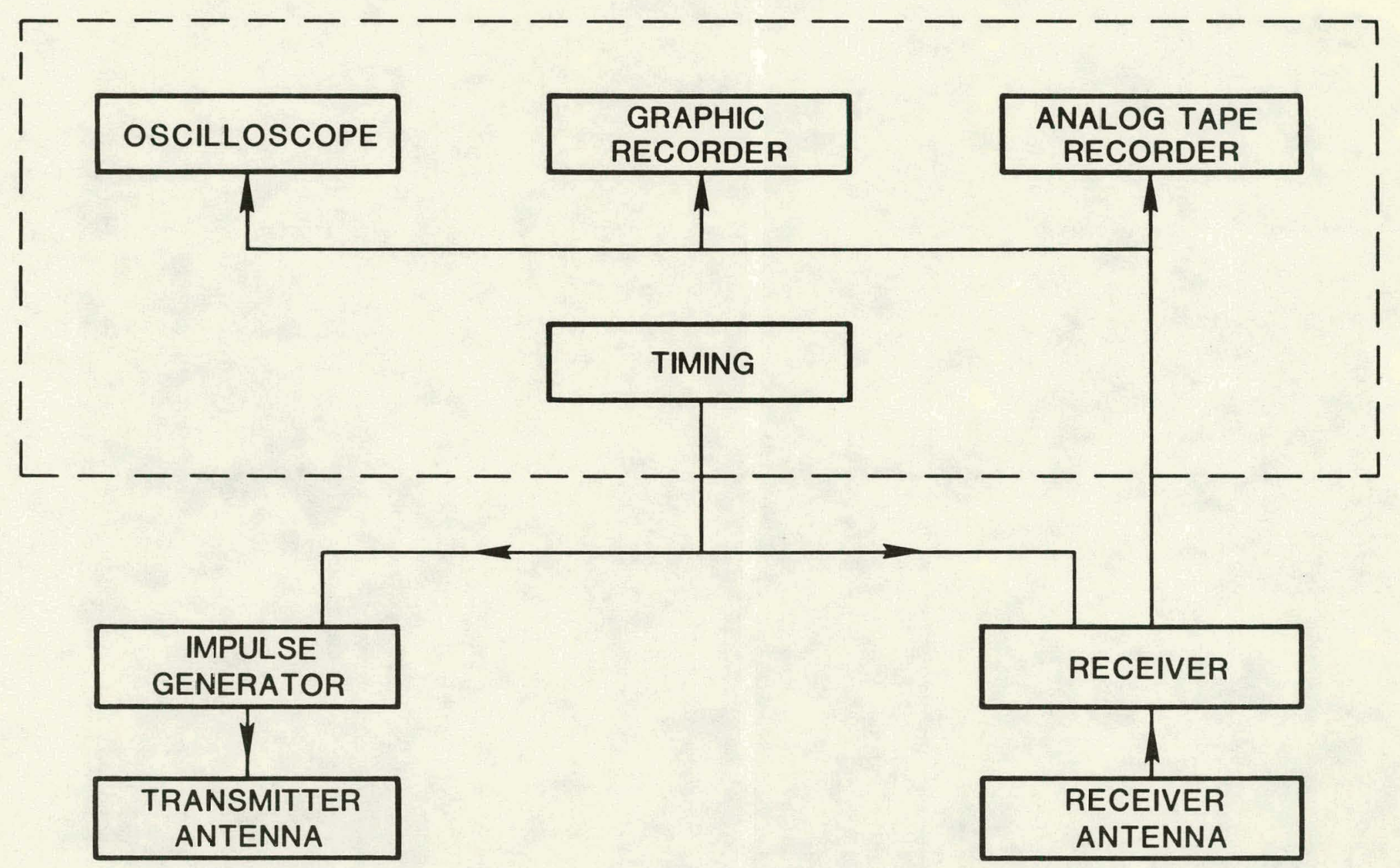

FIGURE 1: BLOCK DIAGRAM OF THE RADAR SYSTEM 
FIGURE 2: RADAR SETUP IN MINE

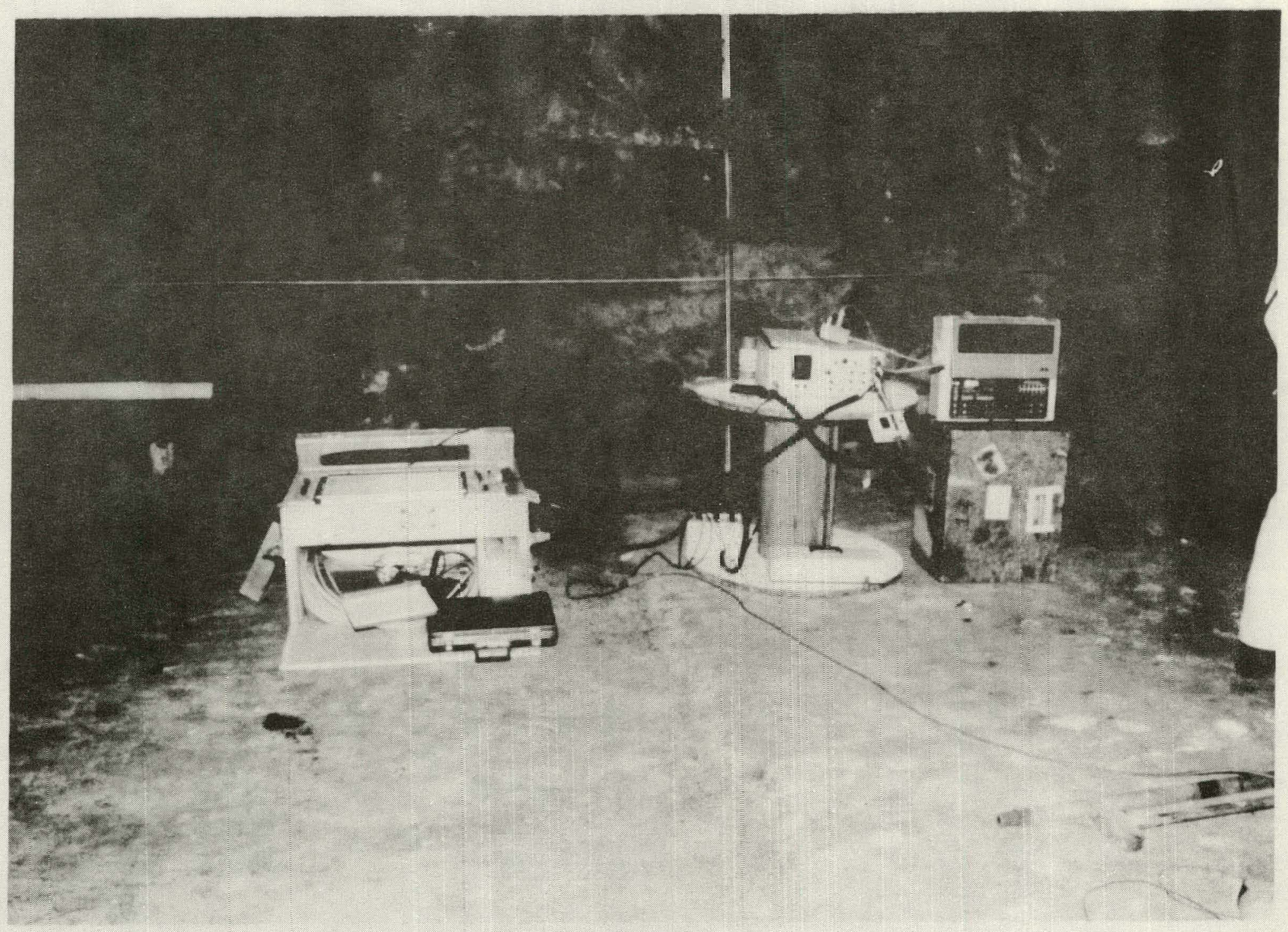




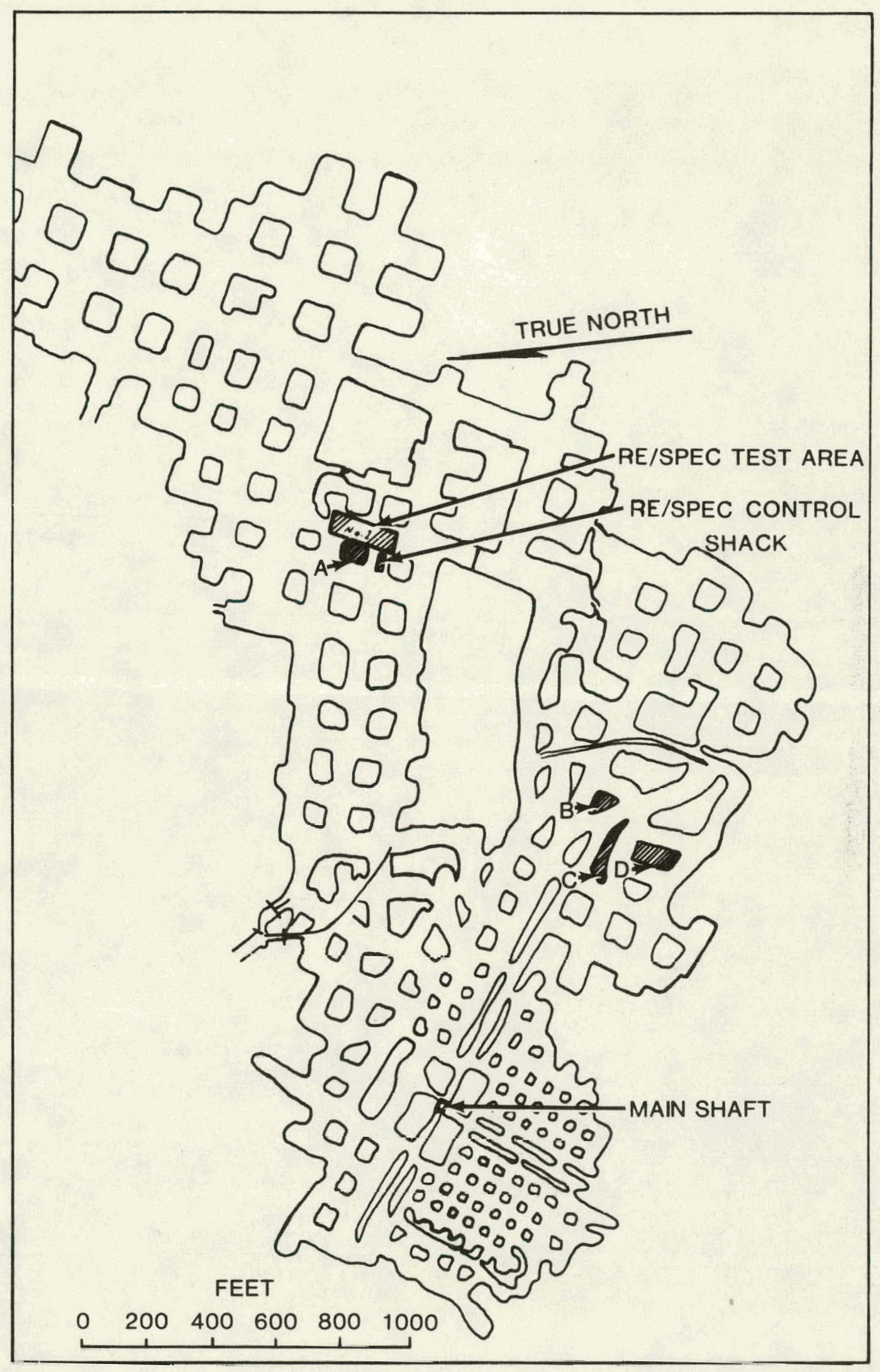

FIGURE 3: A PORTION OF THE 500 - FOOT LEVEL OF THE AVERY ISLAND MINE 

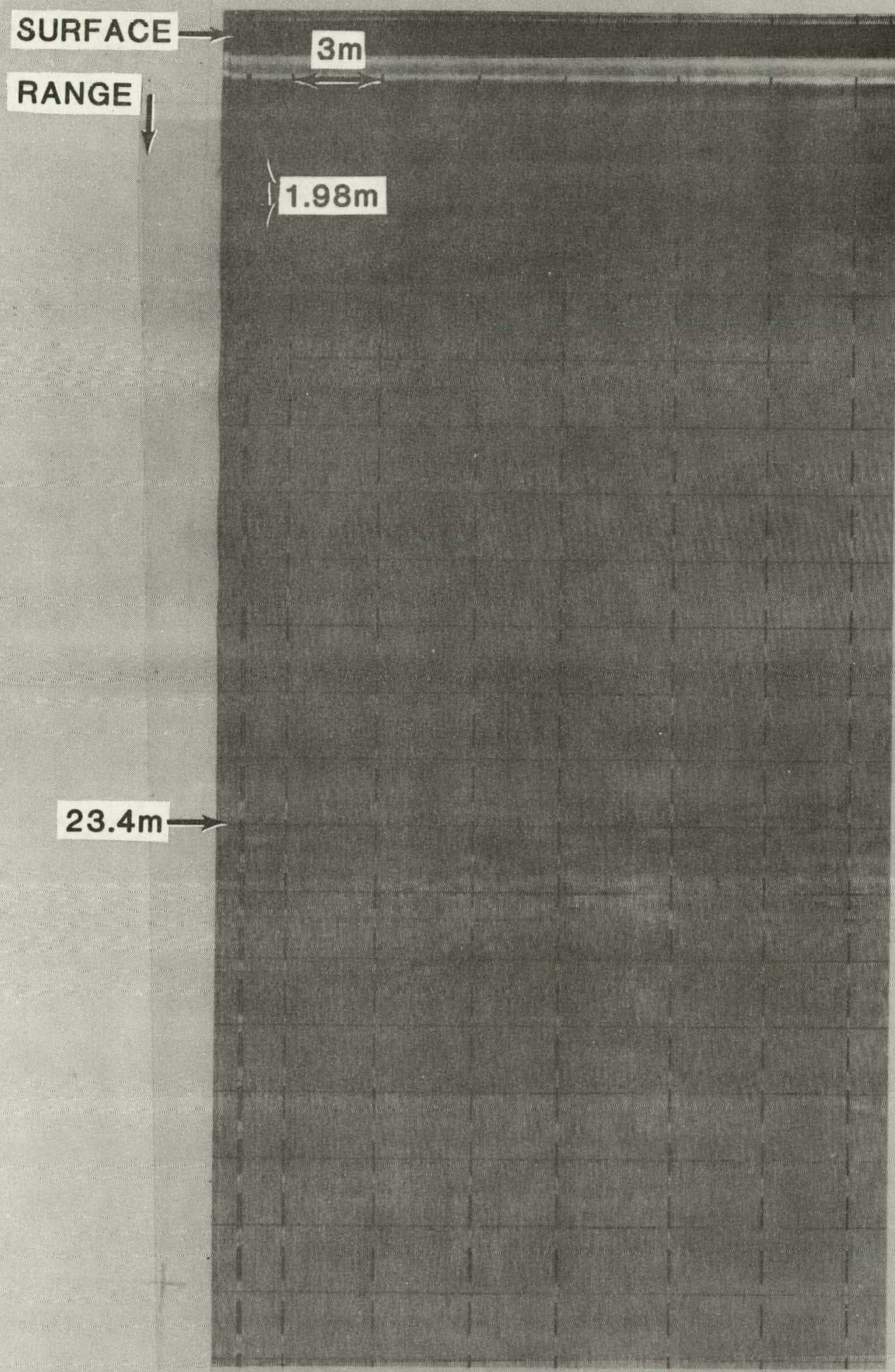

FIGURE 4A: SCAN OF.PILLAR A 


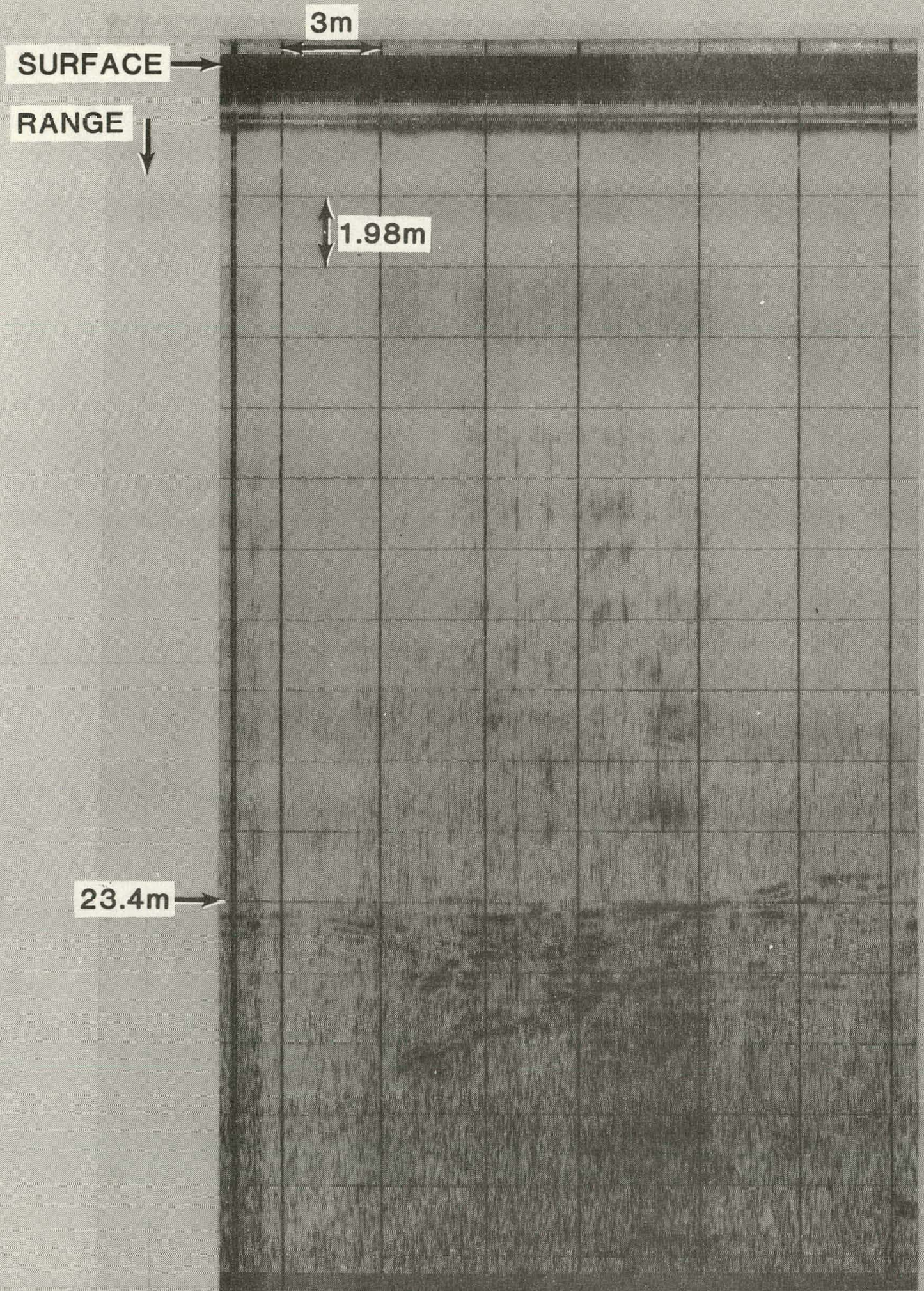

FIGURE 4B: SCAN OF PILLAR A WITH RANGE GAIN 


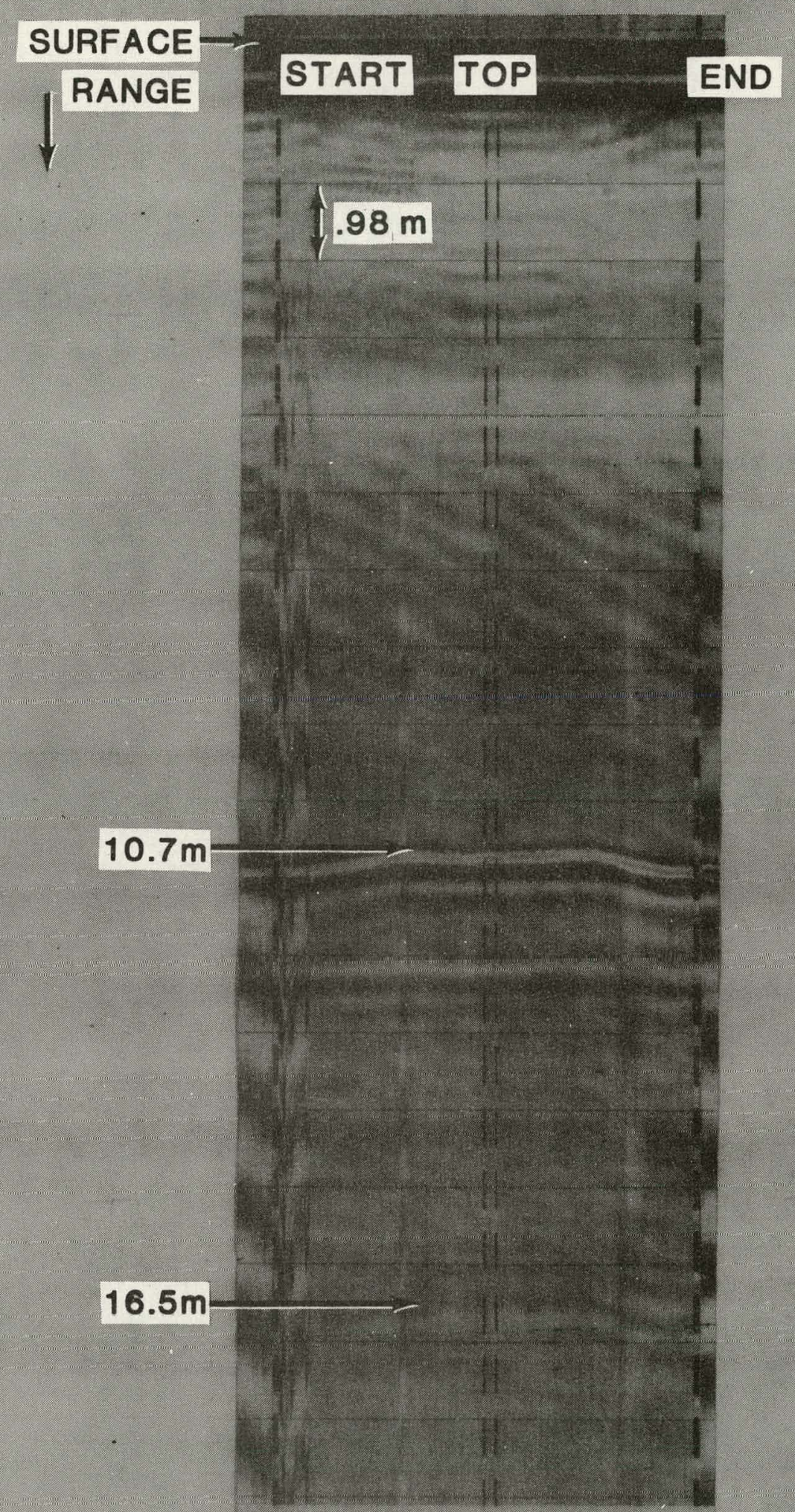

FIGURE 5A: VERTICAL SCAN OF PILLAR A 


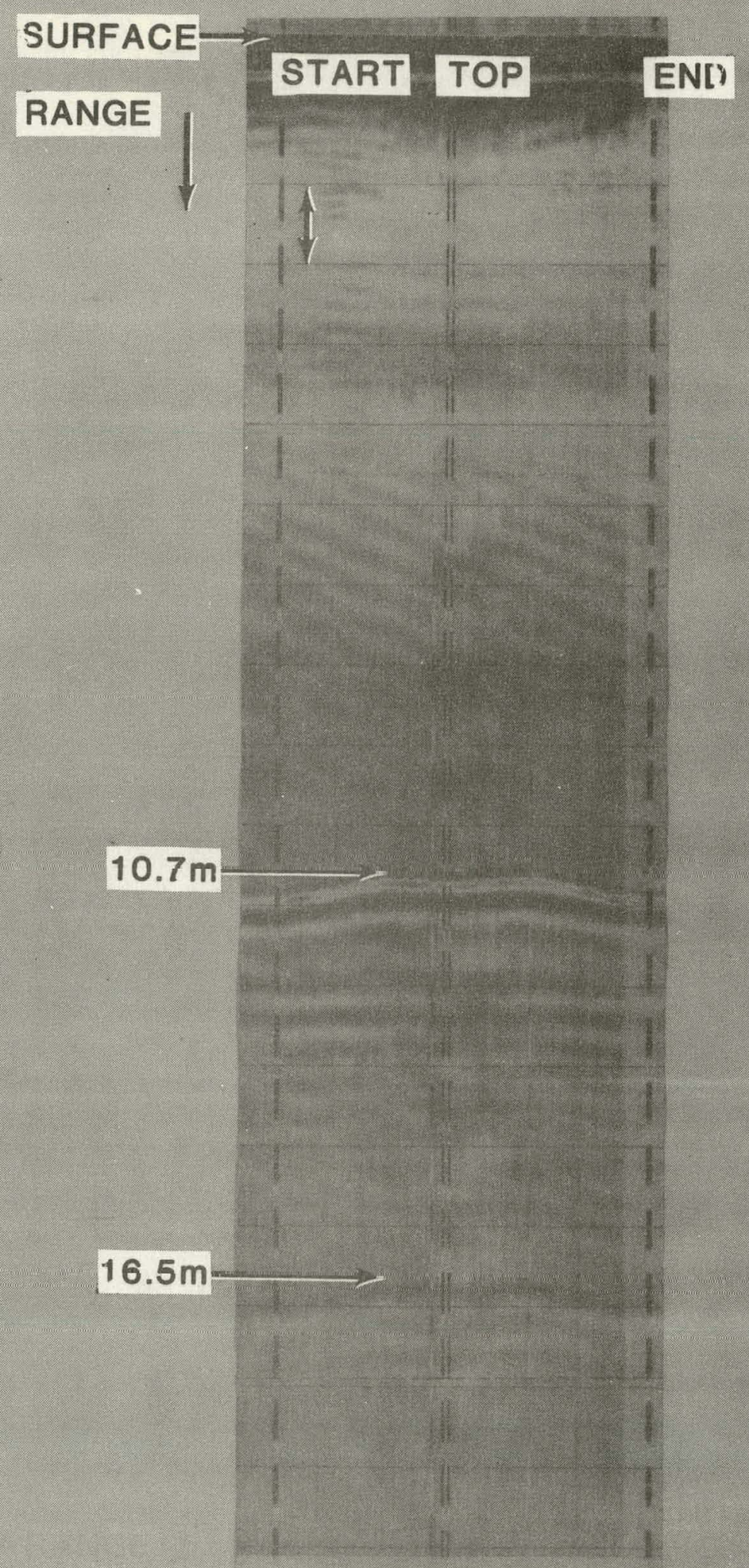

FIGURE 5B: VERTICAL SCAN OF PILLAR A WITH CALIPER IISERTED 


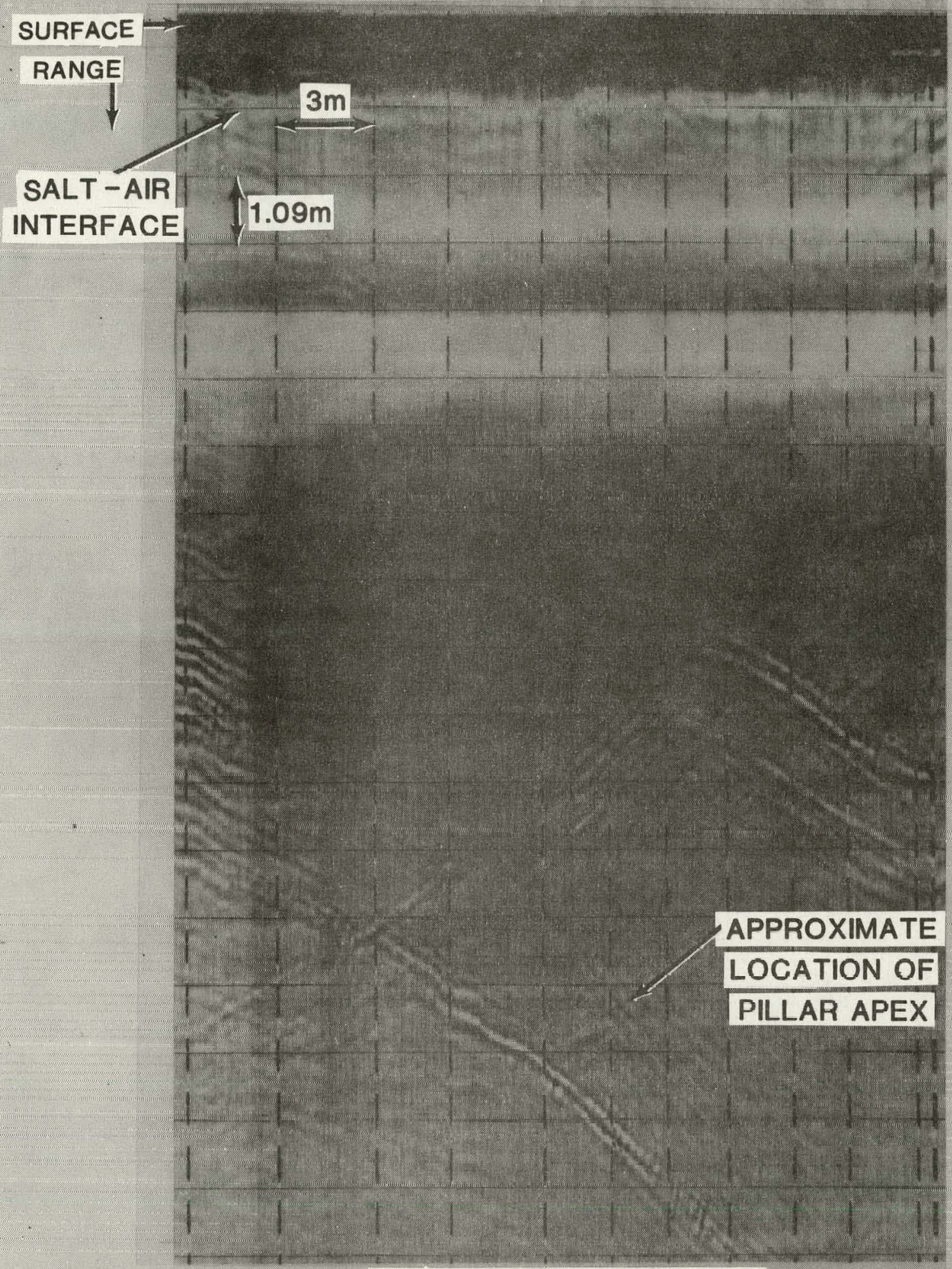

FIGURE 6A: SCAN OF PILLAR B 


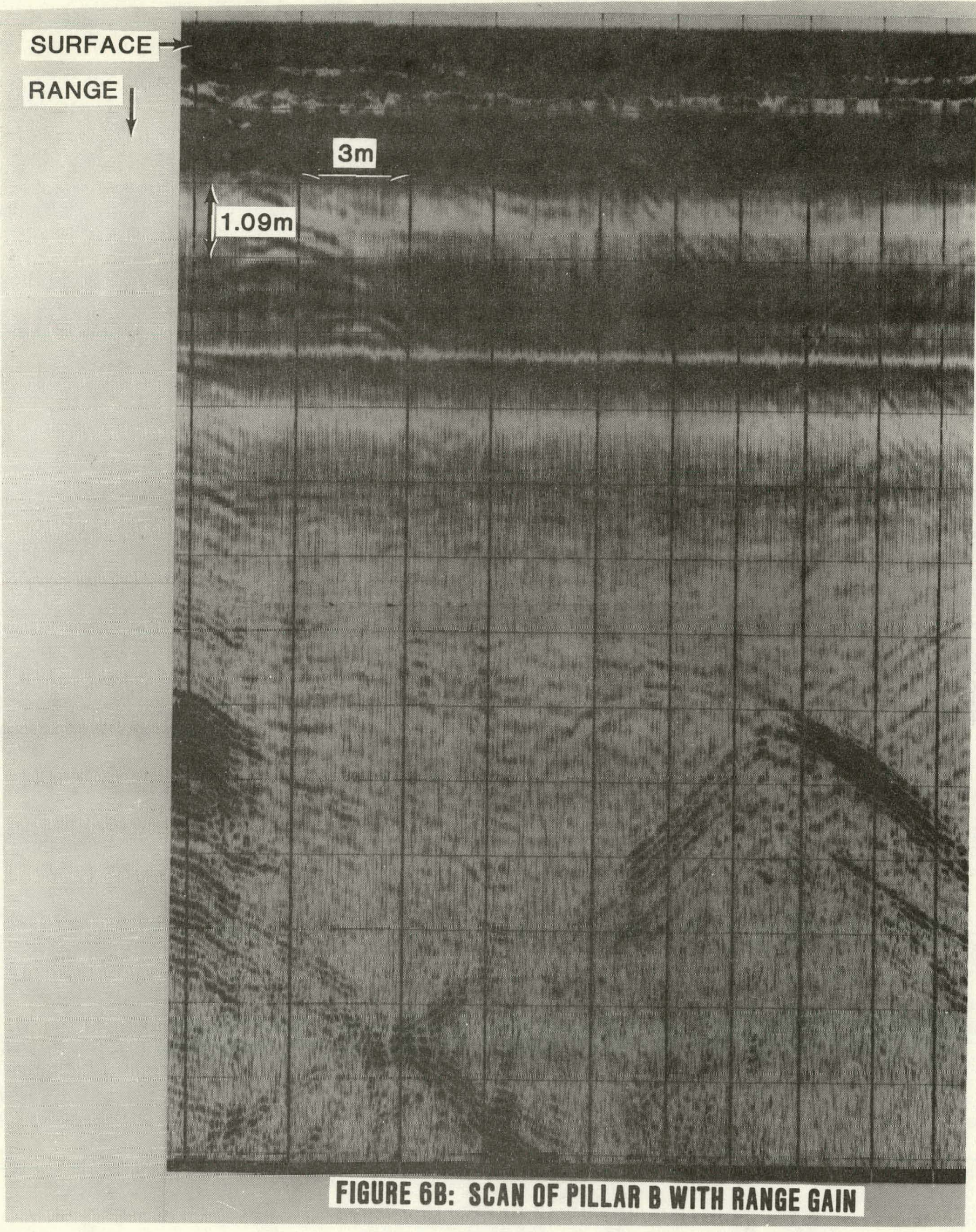




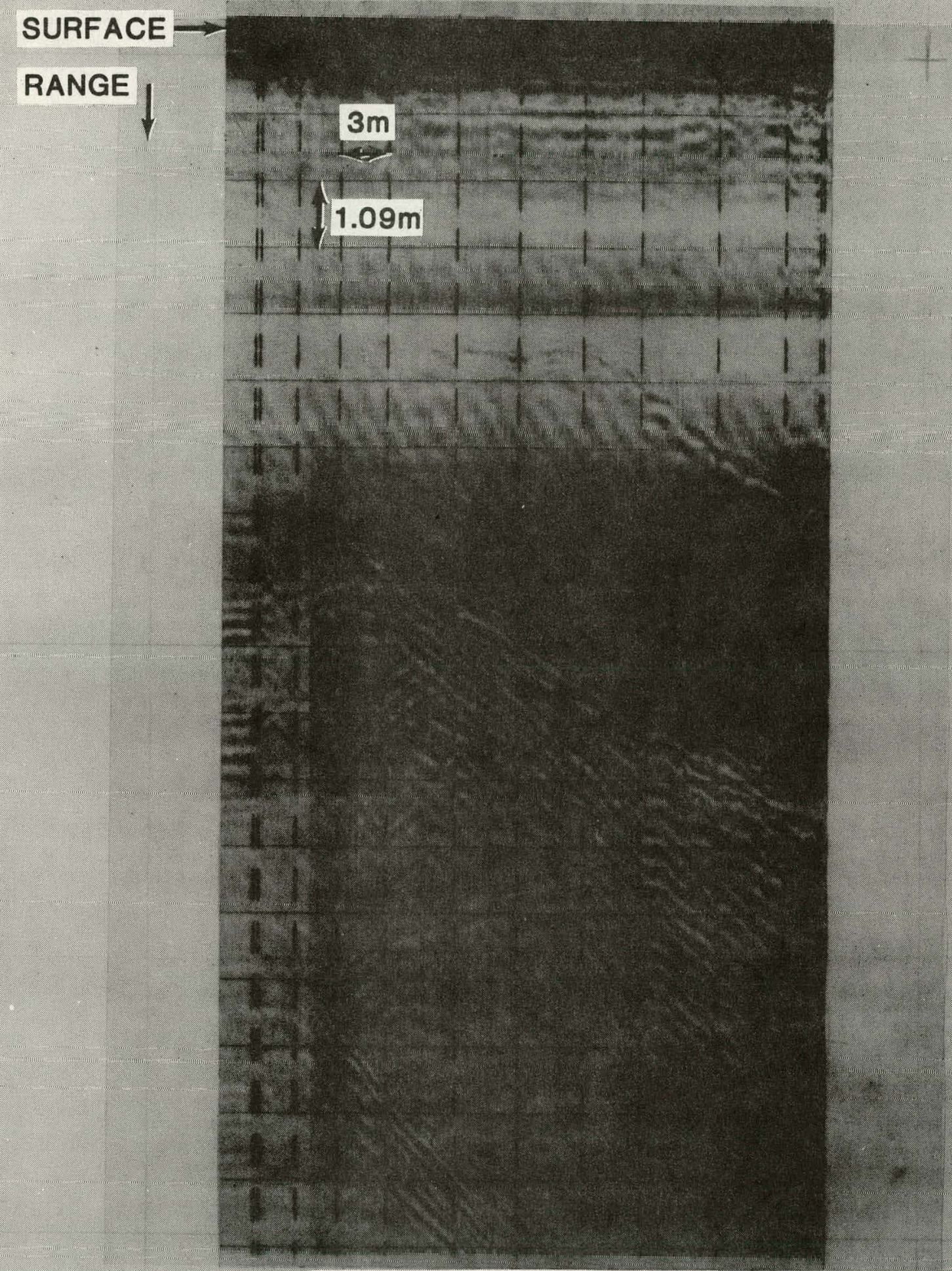

FIGURE 7A: SCAN OF PILLAR C 


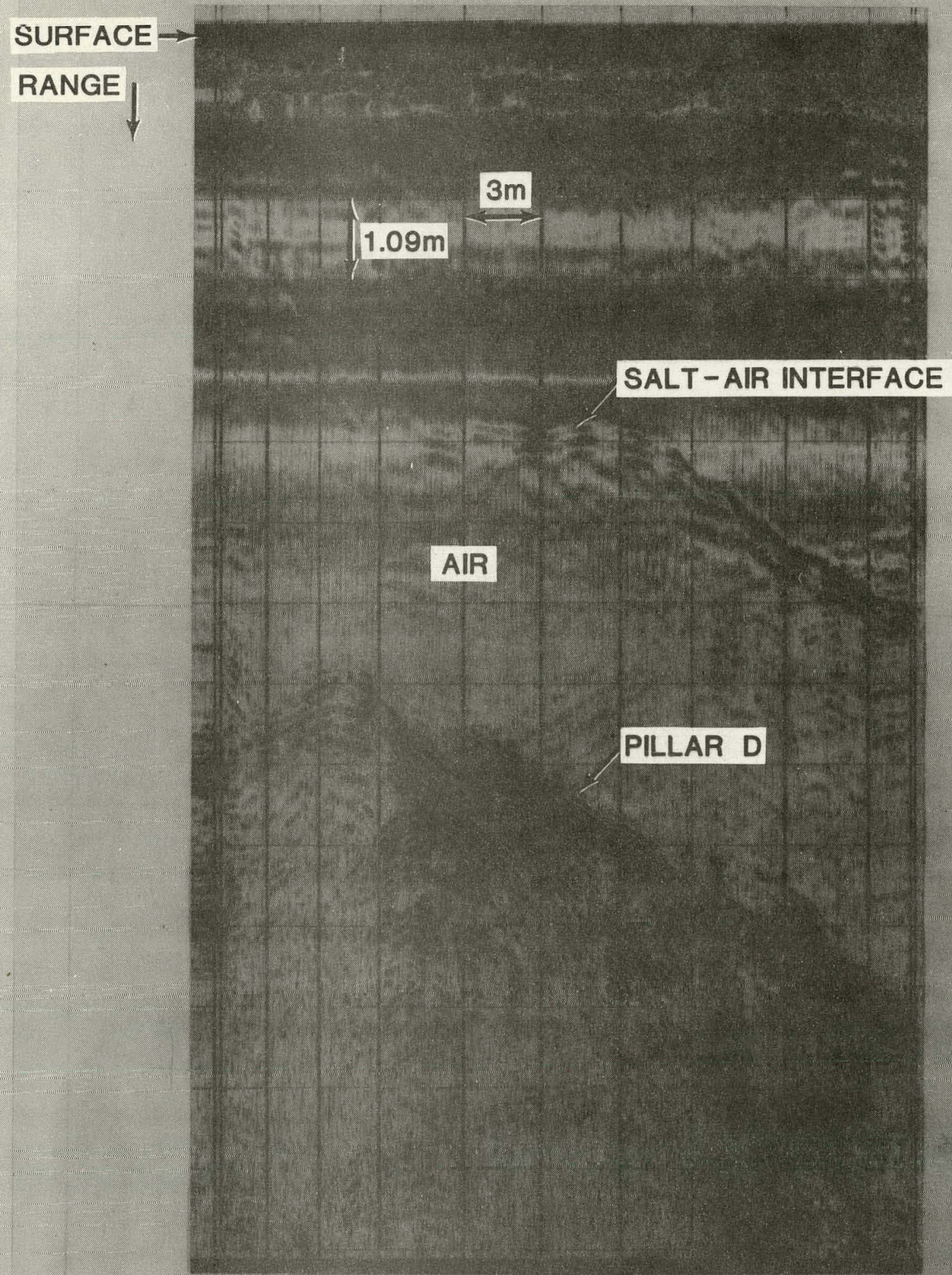

FIGURE 7B: SCAN OF PILLAR C WITH RANGE GAIN 


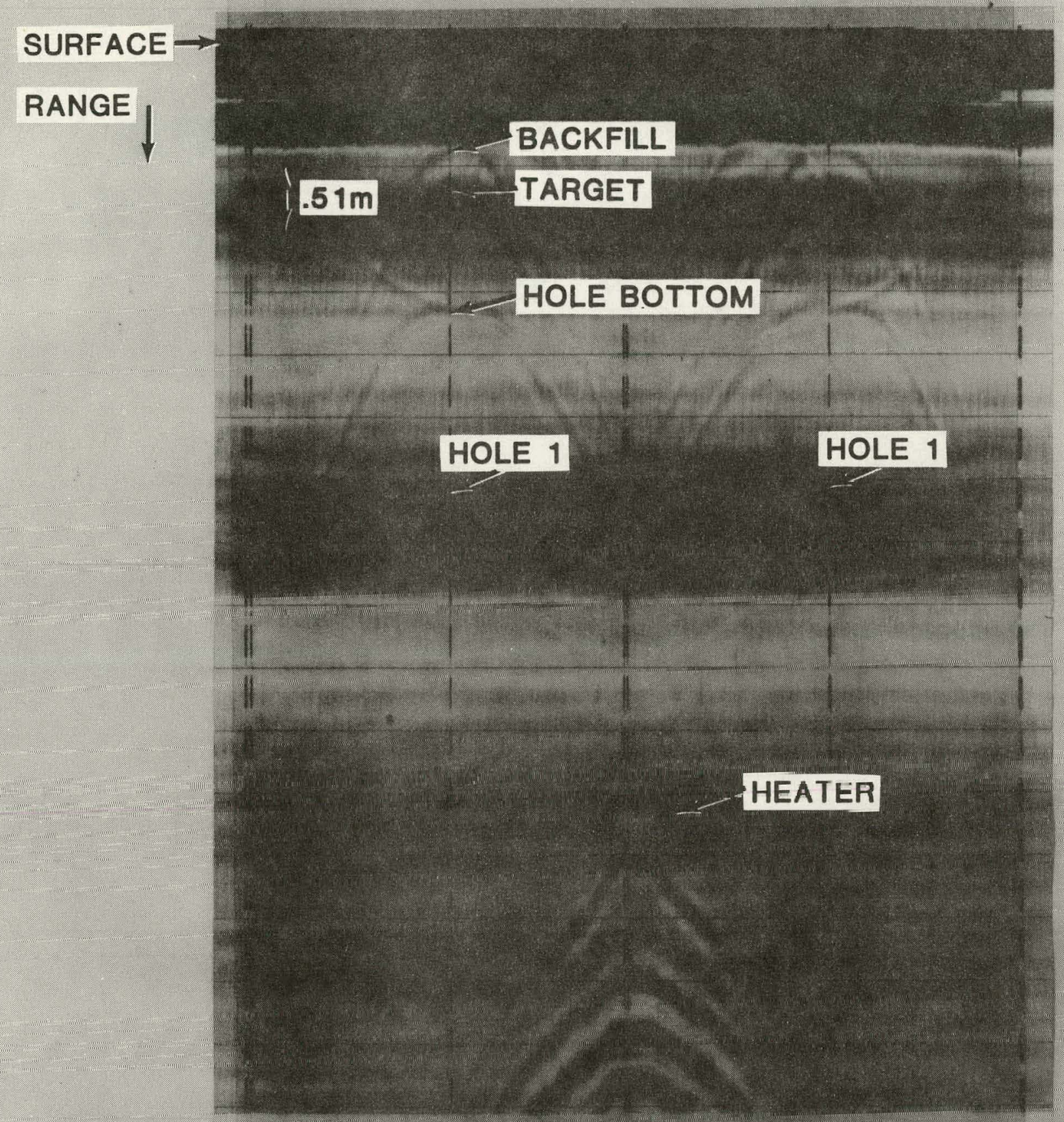

FIGURE 8: SCAN HOLE 1 


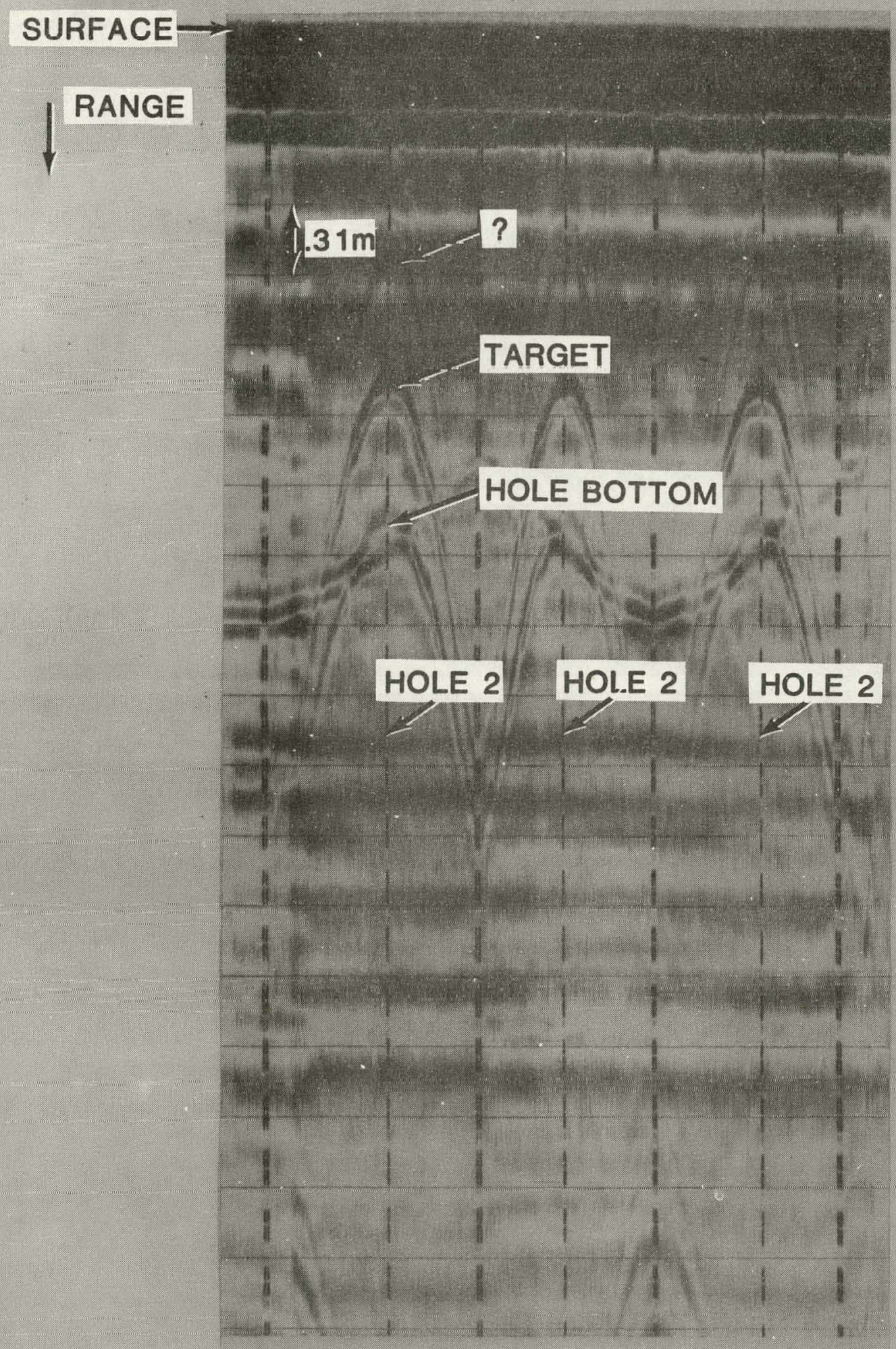

FIGURE 9: SCAN HOLE 2 


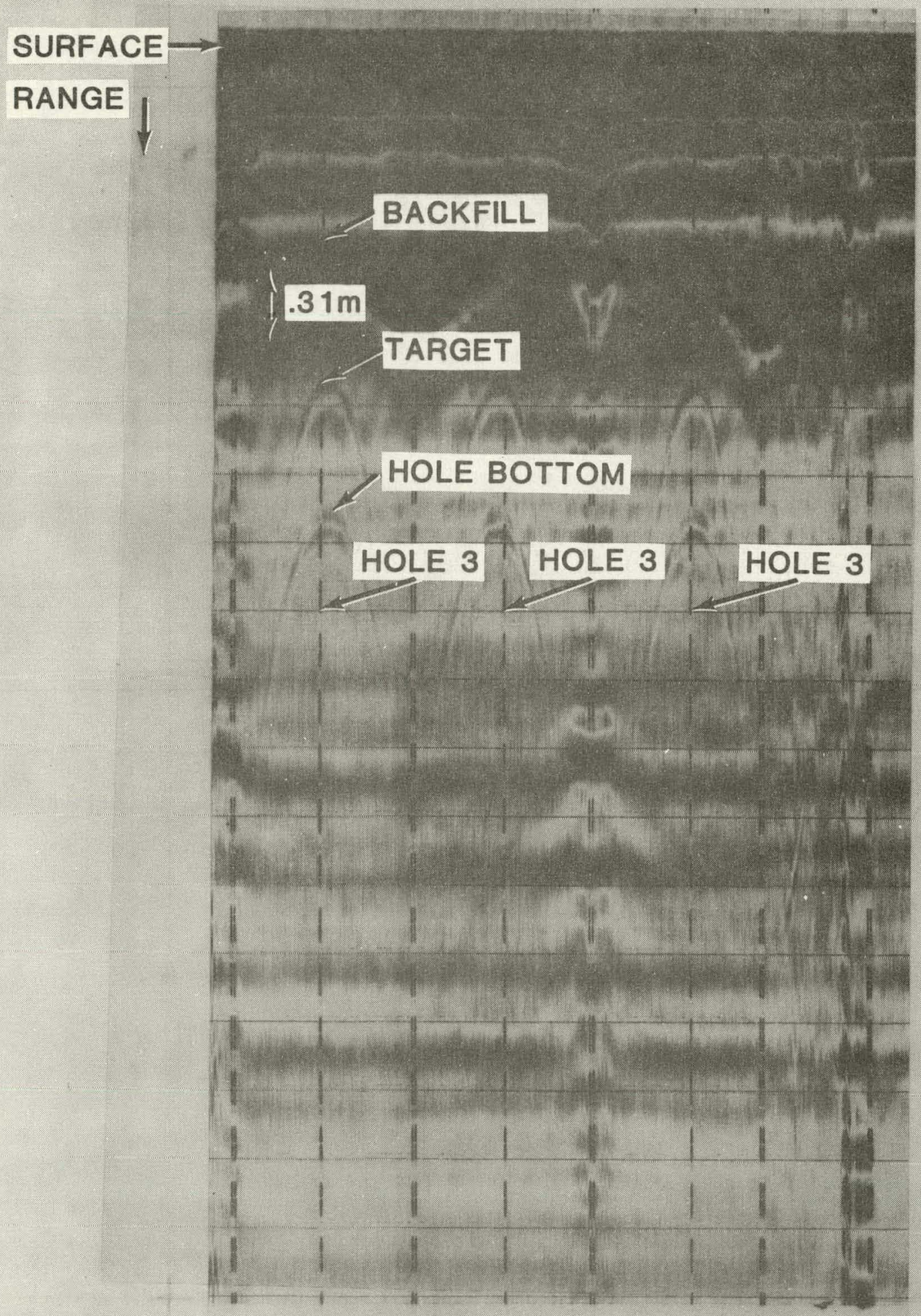

FIGURE 10: SCAN HOLE 3 


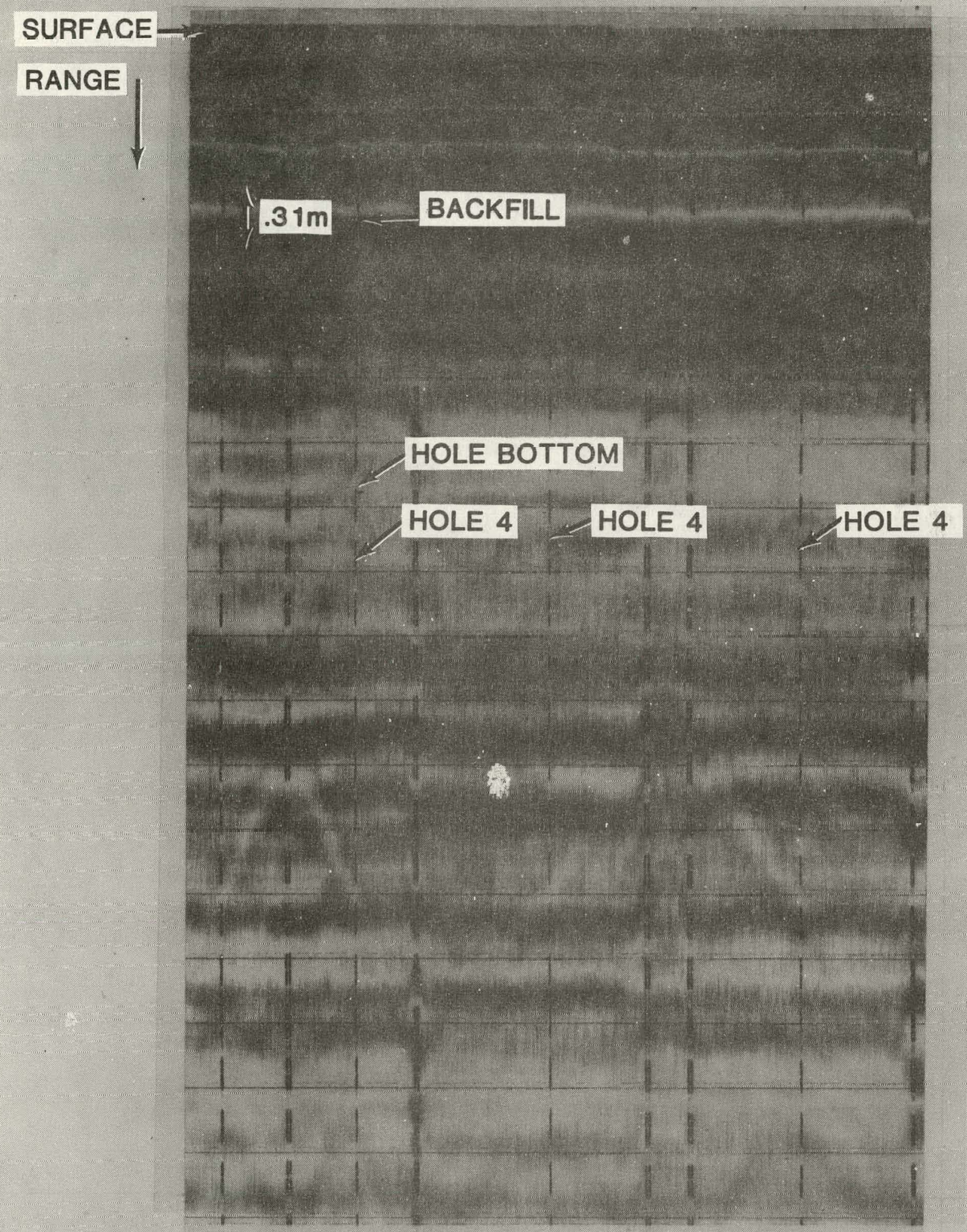

FIGURE 11: SCAN HOLE 4 


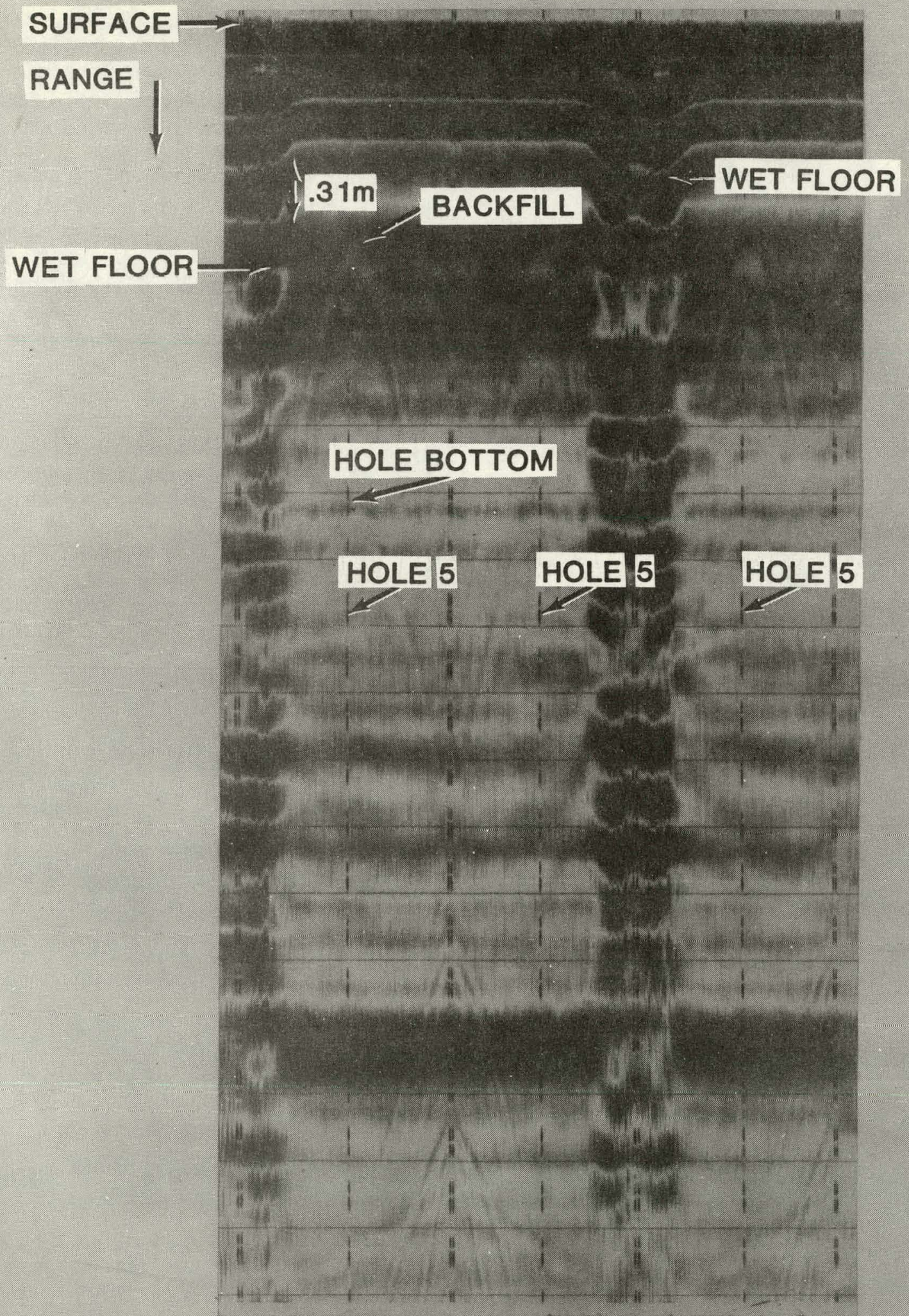

FIGURE 12: SCAN HOLE 5 


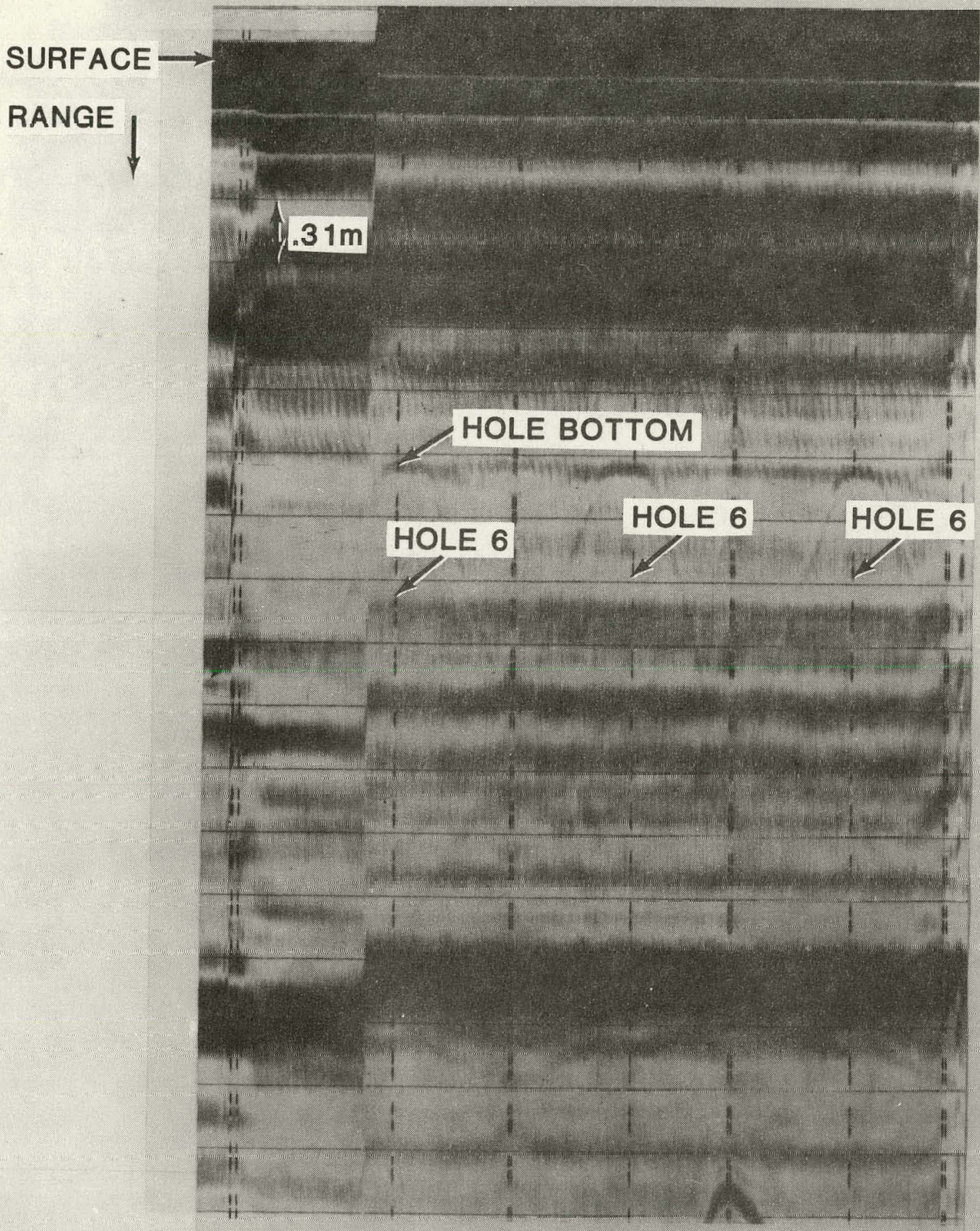

FIGURE 13: SCAN HOLE 6 
U.S. Department of Energy, Headquarters

Office of Nuclear Waste Management

Washington, DC 20545

Eugene F. Beckett, Project Coordinator (WIPP) (I)

Colin A. Heath, Director, Division of Waste Isolation (2)

Sheldon Meyers

Raymond G. Romatowski

R. Ste in

Carl L. Cooley

U.S. Department of Energy, Albuquerque Operations

P.O. Box 5400

Albuquerque, NM 87185

D. T. Schueler, Manager, WIPP Project Office (2)

G. Dennis, Director, Public Affairs Division

S. C. Taylor, C\&TI Division (for Public Reading Rooms)

U.S. Department of Energy

Carlsbad WIPP Project office

Room 113, Federal Building

Carlsbad, NM 88220

U.S. Department of Energy

c/o Battelle

Office of Nuclear Waste Isolation

505 King Avenue

Columbus, $\mathrm{OH} \quad 43201$

Jeff 0 . Neff

Battelle Memorial Institute

Office of Nuclear Waste Isolation

$505 \mathrm{King}$. Avenue

Columbus, $\mathrm{OH} 43201$

Neil Carter, General Manager (3)

R. Heineman

Wayne Carbiener

P. Hoffman

ONWI Library

Westinghouse Electric Corporation

P.O. Box 40039

Albuquerque, NM 87196

R. C. Mairson (3)

Hobbs Public Library

509 N. Ship Street

Hobbs, NM 88248

Ms. Marcia Lewis, Librarian 
Lokesh Chaturvedi

Department of Civil Engineering

Box 3E

New Mexico State University

Las Cruces, NM 88003

Bechtel Inc.

P. O. Box 3965

San Francisco, CA 94119

R. A. Langley

National Academy of Sciences, WIPP Panel

Frank L. Parker, Chairman

Department of Environmental and

Water Resources Engineering

Vanderbilt University

Nashville, TN 37235

Konrad B. Krauskopf, Vice Chairman

Department of Geology

Stanford University

Stanford, CA 94305

Dr. Karl P. Cohen, Member

928 N. California Avenue

Palo Alto, CA 94303

Neville G. W. Cook, Member

Dept. of Material Sciences and Engineering

University of California at Berkeley

Heart Mining Building, \#320

Berkeley, CA 94720

Merril Eisenbud, Member

Inst. of Environmental Medicine

New York University Medical Center

Box 817

Tuxedo, NY 10987

Fred M. Ernsberger, Member

Glass Research Center

PPG Industries, Inc.

Box 11472

Pittshurgh; PA 15238

Roger Kasperson, Member

Center for Technology, Environment and Development

Clark University

Worcester, MA 01610

Richard R. Parizek, Member

Department of Hydrogeology

Pennsylvania State University

University Park, PA 16802 


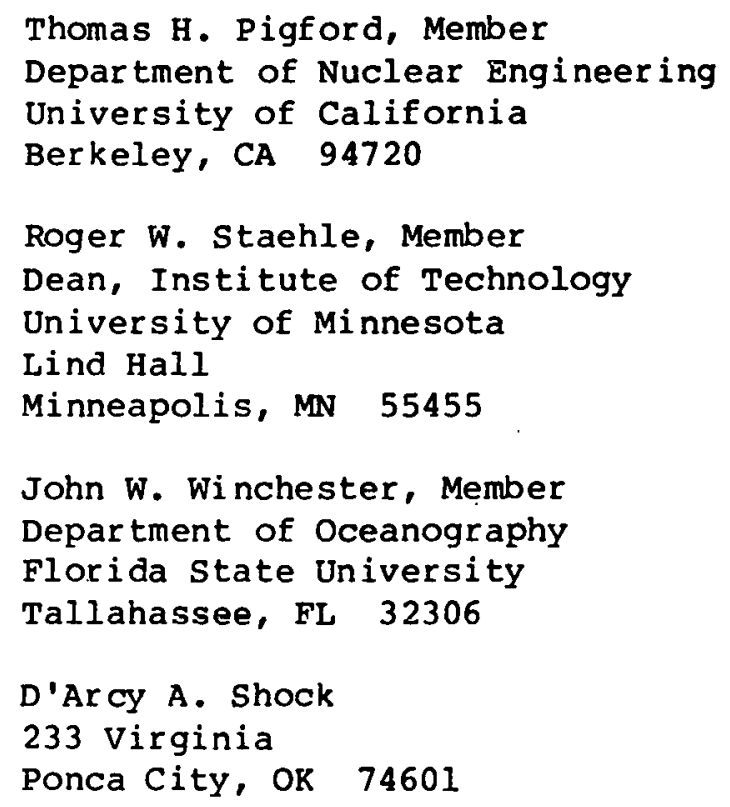

Committee on Radioactive Waste Management

John T. Holloway, (2)

2101 Constitution Avenue, NW Washington, DC 20418

WIPP Public Reading Room

Atomic Museum, Kirtland East AFB

Albuquerque, NM 87185

Ms. Gwynn Schreiner

WIPP Public Reading Room

Carlsbad Municipal Library

$101 \mathrm{~s}$. Hallagueno st.

Carlsbad, NM 88220

Lee Hubbard, Head Librarian

Thomas Brannigan Library

$106 \mathrm{w}$. Hadley $3 \mathrm{t}$.

Las Cruces, NM 88001

Don Dresp, Head Librarian

Roswell Public Library

$301 \mathrm{~N}$. Pennsylvania Avenue

Roswell, NM 88201

Ms. Nancy Langston

Bruno Giletti

Department of Geological Sciences

Brown University

Providence, Rhode Island 02912 
RE/SPEC Inc.

P. O. 725

$\frac{\text { Rapid City, SD } 57701}{\text { Dr. P. Gnirk }}$

R. Stickney

Mr. Michael J. Smith

Rockwell International

Atomics International Division

Rockwell Hanford Operations

P. O. Box 800

Richland, WA 99352

Systems, Science, and software

Box 1620

La Jolla, CA 92038

E. Peterson

U.S. Geological Survey

Special Projects

MS954, Box 25046

Denver Federal Center

Denver, Co 80255

C. Jones

J. Mercer

U.S. Geological Survey

P. O. Box 26659

Albuguerque, NM 87125

$$
. T \text { : Mercer }
$$

Sandia Internal

1100 C. D. Broyles

1110 J. D. Plimpton

1112 C. R. Mehl

1112 R. I. Ewing

1112 J. J. Hohlfelder

1112 G. Miller

1116 S. R. Dolce

1.1.1.6 E. S. Ames

1116 C. W. Cook (5)

1120 T. L. Pace

1125 G. L. Ogle

1125 J. I'. Micilmoyle

1130 H. E. Viney

1133 R. D. Statler

3141 T. L. Werner (5)

3151 W. L. Garner, For: DOE/TIC (Unlimited Release) (3)

3154-3 R. P. Campbell, For: DOE/TIC (25)

3310 W. D. Burnett 
Raymond Siever

Department of Geological sciences

Harvard University

Cambridge, Massachusetts 02138

John Handin

Center of Tectonophysics

Texas A \& M University

College station, Texas 77840

John Lyons

Department of Earth Sciences

Dartmouth College

Hanover, New Hampshire 03755

George Pinder

Department of Civil Engineering

Princeton University

Princeton, New Jersey 08540

New Mexico Advisory Committee on WIPP NMIMT Graduate office

Socorro, NM 87801

$$
\text { Marvin H. Wilkening, Chairman (2) }
$$

State of New Mexico

Environmental Evaluation Group

320 Marcy Street

P.O. Box 968

Santa Fe, NM 87503

Robert H. Neill, Director

NM Department of Energy \& Minerals

P. O. Box 2770

Santa Fe, NM 87501

Larry Kehoe, Secretary

Kasey LaPlante, Librarian

J. E. Magruder

Sandia Carlsbad Representative

401 North Canal Street

Carlsbad, NM 88220

D'Appolonia Consulting Engineers, Inc. 10 Duff Road

Pittsburgh, PA 15235

L. Jarolimek

Oak Ridge National Laboratory

Box Y

Oak Ridge, TN 37830

Attn: R. E. Blanko

L. R. Dole 
4500 E. H. Beckner

4510 W. D. Weart

4511 D. W. Powers

4511 L. J. Barrows

4511 D. D. Gonzalez

4512 T. O. Hunter (5)

4512 C. L. Christensen

4512 D. R. Fortney

4512 M. A. Molecke

4514 M. L. Merritt

4530 R. W. Lynch

4537 L. D. Tyler

4538 R. C. Lincoln

4540 M. L. Kramm

4541 L. W. Scully

454. H. r. Shefelbine

4542 J. W. Mckiernan

4542 J. T. Henderson

4542 Sandla WIPP Central Filec (2) (OD)

4732 A. R. Sattler

5812 C. J. Nor thrup 


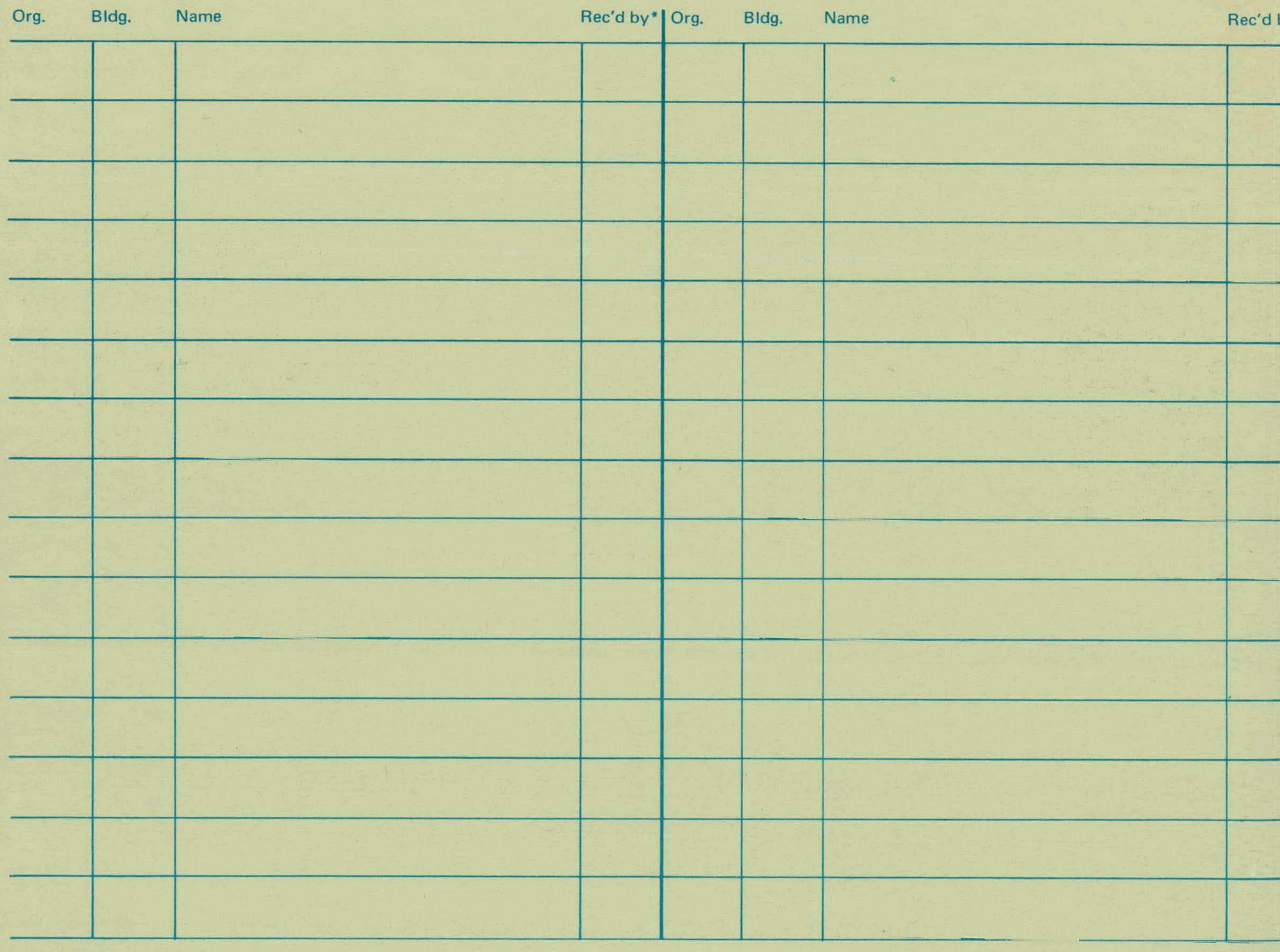

* Recipient must initial on classified documents. 